\title{
BAKER v. CARR ABROAD: THE SWISS FEDERAL TRIBUNAL AND CANTONAL ELECTIONS
}

\author{
F. WILLIAM O'BRIEH'
}

ON March 26, 1962, the Supreme Court of the United States handed down its decision in the Tennessee malapportionment case. ${ }^{1}$ By a strange coincidence, two days later the highest court in Switzerland, le Tribunal Fédéral, pronounced judgment in a case ${ }^{2}$ whose basic issues were strikingly similar. In each case judgment was in favor of plaintiffs claiming curtailment of electoral rights by the respective local units of government-state or canton. In each case the complaining citizens rested their challenge on an "equal protection" clause. In each case there arose the burning issue of federal power versus state or cantonal rights, and dissenting judges protested judicial interference in what they asserted to be a purely local and legislative function. ${ }^{3}$ In each case the great question of the nature of representation was involved, with the judiciary virtually choosing between competing bases of representation and competing theories of political philosophy.

Before enlarging upon these issues, a sketch of the major provisions of the Swiss Constitution seems advisable. The Constitution of the United States has sometimes been called "a bundle of compromises." The same might be said of the Constitution of Switzerland. To understand the government of this tiny Confederation, it is necessary to bear in mind that prior to its creation, the cantons had existed as independent, sovereign States. The Confederation, which came forth from the Convention of 1848, was the creature of their hands, and the government thus established was a government of limited and delegated powers. ${ }^{4} \mathrm{~A}$ further guarantee that cantonal sovereignty would not be destroyed

$†$ Professeur de Droit Constitutionnel, Université de Fribourg, Fribourg, Stuisse.

1. Baker v. Carr, 369 U.S. 186 (1962).

2. Geissbühler v. Fribourg, Grand Conseil, Tribunal Fédéral, March 28, 1962, $110 \mathrm{~J}$. Des Tribunaux I, 271 (Swit.).

3. Le Tribunal Fédéral, the highest court in Switzerland, does not publish dissenting or concurring opinions but only the decision and the judgment of the court. But deliberntions are public so that the positions and views of all judges are generally well known. In this article references to dissenting and concurring opinions rely upon newspaper accounts, personal notes, and the notes of one of the participating judges used at the deliberations and kindly loaned to this writer.

4. Article 3 of the Swiss Constitution reads much like the tenth amendment of the Constitution of the United States. "Les cantons sont sonverains en tant que leur souverainch in'est pas limiteé par la Constitution fédérale, et, comme tels, ils cxercent tous les droits qui ne sont pas déléqués au pouvvoir fédéral." [The cantons are sovereign so far as their sovereignty is not limited by the federal constitution, and as such they exercise all the rights which are not delegated to the federal power.] The tenth amendment reads: "The powers not delegated to the United States by the Constitution, nor prohibited by it to the States, are reserved to the States respectively, or to the people." 
by the new union was made by the provision in Article 71 that the legislative body would be bicameral, with the supporting assurance of Article $\$ 0$ that

The Council of States is composed of forty-four deputies from the Cantons. Each canton appoints two deputies. In divided cantons, each half-canton elects one. ${ }^{5}$

Thus, while Article 72 establishes the National Council of deputies "in the proportion of one member per 24,000 souls," Article 80 gives equal representation to each canton regardless of size or population. ${ }^{0}$

Prior to the adoption of the 17th Amendment in 1913 the United States Senators were chosen by the legislatures of their respective states. In Switzerland, although there is no constitutional provision on this matter, the method of election to the Council of States is completely under the control of each canton. ${ }^{7}$ In four cantons Councillors are chosen by the cantonal legislature; in fifteen and a half cantons the people vote by direct ballot; in two and a half cantons the chore is entrusted to the Landsgemcindc, the open-air meeting of all cantonal voters held each spring in the town square. The cantonal legislatures likewise determine the terms of the members they send to the Council of States. In three cantons the term is three years, in one canton it is a single year, in the others four years. By contrast to the above, Article 73 provides for direct election to the National Council and Article 76 fixes the term of deputies at four years. Quite evidently, the Council of States was created to preserve the federal feature in the government of Switzerland. As another concession to the proponents of cantonal autonomy, only one federal court, not an entire system, was established. Cantonal courts exercise jurisdiction over federal matters. $^{8}$ True to the political philosophy of legislative supremacy, the constitutional makers did not bestow on the Federal Tribunal the power to declare acts of parliament unconstitutional, and there is no evidence that the Swiss entertain regrets on the matter. ${ }^{9}$ Consistent with their distrust of judicial supremacy, the people have not given their cantonal courts authority to control their cantonal legislatures, except in the Canton of Geneva. ${ }^{10}$

5. Le Conseil des Etats se consose de 44 députés des cantons. Chaque conton nomme deux députés; dans les cantons partagés, chaque demi-Etat en élit un.

6. Article 84 underscores the "delegated powers" feature of Article 3: "Le Conscil national et le Conseil des Etats délibèrent sur tous les objets que la présente Constitution place dans le ressort de la Confédération et qui ne sont pas attribués à une autre aulorité fédérale." [The National Council and the Council of States deliberate on all matters which the present Constitution places within the competence of the Confederation, and which are not assigned to any other federal authority.]

The words "confederation" and "federation" do not have the same distinct meaning in Switzerland as in America. Note that in The Froeralist Papers, Hamilton used the words with similar looseness.

7. Hughes, The Federal Constitution of Switzerdand 88 (1948).

8. Codding, THe Federal Governarent of SwitzerLaNd 110 (1961).

9. One attempt to add judicial review to the powers of the Tribunal was made in 1939 by popular initiative, but it was defeated in a decisive manner. Id. at 112 .

10. Rappard, Le contrôle de la constitutionnalité des lois fédérales par le juge auıs Etats-Unis et en Suisse, in 53 Zerrschrift Für Schwetzeriscres Recri 111 n n.104 (1934). 
The Swiss case under study here involved the system known as proportional representation. ${ }^{11}$ It will be best understood in reference to the majority system prevalent in the United States and in Great Britain. Tennessee, for example, is divided into 99 districts or counties, each of which elects one delegate to its own House of Representatives. This "single-member district system" for electing legislators is generally cited as the major reason for the development of the two-party system in the United States and in Great Britain, and for the meager success of minor-party movements. If a political group can attract only 20 or 30 per cent of the voters, it can never successfully encounter the more dominate elements within a district competing for the one representative. It thus either disintegrates as a party or joins in coalition with one of the two major parties, exacting concessions as its terms for the alliance. The "singlemember district" system contributes to the making of stable government. It mollifies rigid doctrines and thereby helps prevent the fractionizing of society into implacable dissident political sects. It removes from the law-making channels a major irritant and barrier, for it prevents entrance to the legislative chamber of parties too small to govern but large enough to obstruct.

On the other hand, critics view this system as unjust and undemocratic. $A$ party may command the faithful allegiance of 10 or even 30 per cent of the popular vote and still fail to obtain a single seat in the legislative body. ${ }^{12}$ It is objected that every appreciable view in society should be reflected in a truly representative government and that citizens should not be virtually compelled to affiliate with other parties in whose political tenets they place only minimal credence.

Out of such theorizing came proportional representation, the system whereby the Swiss elect their National Council and at least seventeen of their cantonal legislatures. ${ }^{13}$ It has many variations ; the following example of the "list" system demonstrates the workings of proportional representation only in its least complicated form. Here each party presents to the voters a list of candidates equal to the number of seats allotted to the district. If the district is entitled to six representatives, and if three parties compete at the polls, the distribution of seats will first demand that an "electoral quotient" be established. For example, in Veveyse, one of the districts in Fribourg, suffrages for three parties totaled 10,439 for the 1961 elections, and the quotient was thus

11. Finer, Theory and Practice of Modern Governarent 554-55 (1949), gives a description of the system with a well balanced criticism.

12. These arguments have never generally commanded the attention of Americans. Only 12 cities-Cincinnati being the largest-employ the system. After a ten-year trial, New York City abandoned the plan in 1947. OgG \& RAY, Intropuction to Asserucan GoverNMRENT 864 n.5 (11th ed., 1956).

13. There are some differences in the structure and powers of the several cantonal governments, but in general the similarities are greater. All of the legislatures are unicameral. The executives are collegiate bodies like the Federal Council, but elected popular1y. There are considerable differences in the structures of the cantonal courts, but since a knowledge of neither their structure nor their powers is necessary for this article, the matter will be omitted. 
1,739.14 The Conservative-Christian-Social Party with 4,665 votes (each voter being entitled to six), was awarded two deputies. The Radical-Socialists with 2,166 received one. The Peasants and Independents Party won two seats with its 3,608 suffrages. Since the Conservative-Christian-Social Party had the largest remainder $(1,187)$ after dividing its 4,665 by 1,739 , it received the seat not distributed in the first "round."

The case of Geissbiihler v. Fribourg, Grand Conscil ${ }^{15}$ arose from the following set of facts. ${ }^{16}$ The constitution of Fribourg was modified in January, 1921 by an addition to Article 36, drafted by the Fribourg Legislature (the unicameral Grand Conseil), and submitted to the people. It read as follows, with the 1921 addition italicized:

The legislative power belongs to a Grand Conseil composed of deputies elected through electoral assemblies according to the systein of proportional representation.

To implement the new constitutional provision the Grand Conseil immediately set about writing an elaborate electoral law which was enacted six weeks later, on March 19, 1921.17 The pertinent section is Article 20, section 3 which reads:

Any list which has not received a number of votes (party votes) equal at least to 15 percent of the total number of votes validly written is eliminated from the apportionment.

The Grand Conseil for the Canton of Fribourg is composed of 130 deputies chosen from eight districts (cercles électoraux) for terms of five years. On December 3, 1961, the canton held its quinquennial elections. In the District of Singine the Conservative-Christian-Social Party won 84,011, or 93.4 per cent of the votes. ${ }^{18}$ The Socialist Party received 5,923 votes, or 6.6 per cent. Since this was far below the 15 per cent quorum, the Socialists were not entitled to any of the 20 seats allotted to Singine. But, according to a system of "pure" proportional representation, the 6.6 per cent would have entitled them to one seat. In the District of the Lac, with 15 deputies, four party lists were presented at the polls. The total number of votes was 56,893 and thus the quorum of 15 per cent was 8,533. ${ }^{19}$ Since the Workers and Employers Party received only 7,085 suffrages, they fell short of the requisite number to entitle them to a seat. Their 12.4 per cent, however, would have merited two seats in a system unmodified by the quorum requirement.

14. Bulletin Officiel des Seances du Grand Conseil du Canton de Frmoung [hereinafter cited as BuLc. du GRANd ConseIr], Dec. 1961, p. 967.

15. Tribunal Fédéral, March 28, 1962, $110 \mathrm{~J}$. Des Tribunaux I, 271 (Swit.).

16. Bull. du Grand Conseir, Dec. 1961, p. 989. Expose sur les Delmerations du Grand Consent au Sujet de la Representation Proportronnelle [hereinafter cited as EXPoSe SUR LES Deliberations] (mimeographed) 1-9. (Material filed by Mr. Nordmann, advocate for appellants in Geissbühler v. Fribourg, Grand Conseil, supra note 15. Sce dossier with court records, Tribunal Fédéral, Lausanne, Switzerland).

17. Ibid. See also 1921 BULLETIN des LoIs de Frrbourg 75.

18. Buld. Du Grand Consen, Dec. 1961, p. 956.

19. Id. at 960 . 
The Conseil d'Etat (the executive body of the Canton) verified the election returns on December 12, 1961. ${ }^{20}$ The Socialist Party of Singine and the Workers and Employers Party of the Lac filed an appeal which both the Con-

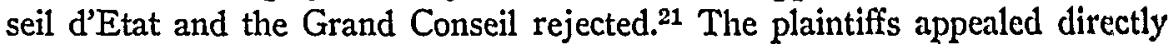
to the Federal Tribunal, grounding their complaint upon three contentions.a First, Article 20, paragraph 3, of the electoral law of March 19, 1921, eliminating any party not receiving 15 per cent of the valid votes, violates Article 36 of the Fribourg Constitution, which provided for a system of unqualified proportional representation. Second, the law is arbitrary and offends Article 4 of the Federal Constitution, which states that "All Swiss are equal before the law." Third, it is contrary to Article 9 of the cantonal constitution, which reads that "All citizens are equal before the law."

According to the Swiss rules of procedure, the Federal Tribunal is not authorized to nullify a cantonal law, even though judged unconstitutional, if an appeal is delayed beyond thirty days of its enactment. ${ }^{23}$ The Tribunal is, however, empowered to set aside the application of the law in the case before it. In Geissbiihler v. Fribourg, Grand Conseil, the court was thus restricted. Its ruling was as follows: ${ }^{24} 1$ ) Article 36 of the cantonal constitution did not inhibit the Grand Conseil from establishing a quorum as a modification of proportional representation. 2) Article 36 did not permit a quorum as high as 15 per cent. 3) The decision of the Grand Conseil of December 27, 1961, rejecting the claim of the Workers and Employers Party to two seats by reason of their 12.4 per cent of total suffrages in the District of Lac, is unconstitutional. 4) The decision taken against the Socialist Party in the District of Singine is judged constitutional and need not be set aside.

This ruling commanded the support of five of the seven members of the Tribunal, but the majority were not in full harmony on all aspects of the case. 25 None of the concurring five was willing to state explicitly what per cent would be an acceptable quorum. Judge Pedrini stated that "it would appear" that 10

20. Id. at 969 .

21. Id. at $986-95$.

22. Geissbühler v. Fribourg, Grand Conseil, supra note 15, at 273.

On the right to such an appeal, see Lor FépéRALE d'Organisation Judicalke, Art. 84a (1943) :

Le recours au Tribunal Fédéral est recevable contre une décision ou un arrêté cantonal pour violation:

a. De droit constitutionnels des citoyens.

Also Art. 85a:

Le Tribunal Fédéral connait en outre:

a. Des recours concernant le droit de vote des citoyens et ceux qui ont trait aux élections et aux votations cantonales, quelles soient les dispositions de la constitution cantonale et du droit fédéral régissant la matière.

23. Lot Fédérale d'Organisation Judictatre, Art. 89 (1943). See also Art. 87.

24. Geissbühler v. Fribourg, Grand Conseil, supra note 15, at 276-77.

25. See note 3 supra. For a newspaper account of the deliberations, see La Liberté, March 30, 1962, p. 30. 
per cent would be acceptable and in accord with that established in other cantons. Judge Abrecht deemed that a quorum from 5 to 10 per cent was justifiable, but Judge Haeberlin reserved his opinion as to a quorum of 10 per cent. Judge Panchaud granted the admissibility of a "moderate" per cent. Judge Deggeller agreed that 12.4 per cent was excessive, but he had, quite clearly, great misgivings about infringing on the legislative authority of a canton and suggested that the entire case be sent back to the Grand Conseil of Fribourg for its reconsideration. When this motion was defeated, he went along with the majority.

The two dissenters, Judges Favre and Pometta, spoke with one voice. The interpretation of a provision in the constitution of a canton is exclusively the right of cantonal authorities except in cases of flagrant violations. To admit the appeal was to undertake a legislative function. If the Grand Conseil had erred, the citizens had in their hands the means of rectifying the mistake, the legislative initiative. ${ }^{28}$

In their arguments in the Geissbiihler case, appellants really asked for a ruling on one point only. ${ }^{27}$ The electorate on January 30,1921 had revised the Constitution by a provision calling for proportional representation and without adding any qualification to this provision. From this omission it was concluded that the people had expressed themselves in favor of a "pure" system of proportional representation. The two aggrieved parties thus concurred in asking the court to declare that any modification of the system would be unconstitutional, and, specifically, that the 15 per cent quorum law of March 19, 1921 and the decision taken in pursuance thereof on December 27, 1961 by the Grand Conseil were de facto breaches of the amended Article 36. Although the plaintiffs declared their ideological opposition to any quorum, small or large, they admitted that their case would be totally groundless if the 15 per cent qualification had been written into the Constitution itself. ${ }^{28}$ It is submitted that the Federal Tribunal would have been more prudent and would have been acting more in true judicial character had they addressed themselves to this question alone. The judges instead attempted to make a distinction between admissible and non-admissible quorums-a perilous venture which involved them in airy theorizing on the virtues and values of proportional representation.

26. Art. 28ter. Constrtution DU CANton DE Frrbourg: "6000 citoyens ont le droit de demander l'élaboration, l'abrogation ou la modification d'une loi."

On the practical difficulties involved in employing this right, see Nordsrant, ExposE sur les Formes Exigees par l'INITIATIVe et le Referenduss en Droit Frmourgeors (mimeographed, 1962).

27. Le recours de Droit Public, p. 13, Geissbühler v. Fribourg, Grand Conscil, sıpro note 15 .

28. Observations des Recourants, March 9, 1962, p. 1 (mimeographed); Records, Geissbühler v. Fribourg, Grand Conseil, stipra note 15.

Geneva's constitution requires a 7 per cent quorum and the electoral laws in three other cantons impose quorums as high as $\mathbf{1 0}$ per cent. 
The judges, with some plausibility, could have agreed with appellants on the principal point raised, and answered the question in one simple statement: Yes, the quorum requirement must be in the Constitution (either explicitly or strongly implied). This conclusion does not lack supporting premises, for at the time the revision of Article 36 was undertaken, there does not appear to have been any discussion about modifying it with a quorum. ${ }^{29}$ Moreover, the federal constitution had been amended just two years earlier to demand proportional representation, and the National Council was first elected according to a pure, unaltered system in November, $1919 .{ }^{30}$ It is not unreasonable to conclude that this was the proportional representation for which the electors of Fribourg thought they voted when they cast their ballots for a provision reading almost verbatim like that so recently put into the Constitution of the Confederation. ${ }^{31}$

A wise policy adopted many years ago by the Supreme Court of the United States is the policy of frugality in giving out free judicial advice not necessary for disposing of the case at hand. The Dred Scott decision ${ }^{82}$ and all the untoward consequences that ensued are grim reminders of what departure from this rule can entail. Had the Federal Tribunal of Switzerland exercised more self-denial in the Geissbiihler case, its decision might well have been given a more gracious reception and the court spared acrimonious criticism and loss of esteem. ${ }^{33}$ From the immediate practical point of view, the difference would have been minimal inasmuch as only one seat-that in Singine-would have been affected. Thoughts on the virtues of different systems of representationsubjects for inflamable debate-the high tribunal could have kept buried deep in its own bosom. With one swift but unoffending stroke of the pen, the judges, in effect, could have deleted the quorum requirement and invited the Canton of Fribourg to express its will firmly in the Constitution, this time with greater care and clarity. Instead the legislation is still on the statute books and could be applied in the next election. At least Fribourg could, with impunity, apply a 12.3 per cent quorum, for the Court's ruling was simply that a 12.4 per cent quorum was too high. If so, appellants may have won the battle but lost the campaign.

The court's "advisory opinion" was intended to suggest to the Federal Tribunal a wiser and more justifiable course in changing the Fribourg law. But the author of this article does not believe that the wording of Article 36 inhibited the cantonal Grand Conseil from enacting the March 19, 1921 electoral

29. See note 16 supra. Defendants apparently did not deny this point.

30. Codping, op. cit. supra note 8 , at 75 .

31. But see notes 51 and 52 infra and accompanying text.

32. Scott v. Sanford, 60 U.S. 393 (1857).

33. La Liberté, the leading newspaper in the city of Fribourg, spoke out sharply against the decision. (March 30, 1962, p. 30.) "Cantonal sovereignty is trampled under foot." Its political editor wrote that "the people of Fribourg are under tutelage" and that "the Federal Tribunal had violated the principle of separation of powers by its decision." Many members of the legal profession stamped the court's decree as the activity of "political" judges. 
law with the 15 per cent quorum. First, all seven members of the court admitted that the wording of the constitutional revision of January, 1921 put no obstacles in the path of further legislative modification, even of a quorum qualification. ${ }^{34}$ This admission, it seems, should have destroyed the whole basis for the appellants' argument, which drew its strength largely from a study of the legislative history of the constitutional revision, prior and immediately subsequent to its adoption. In the study presented to the Federal Tribunal, ${ }^{35}$ M. Nordmann, advocate for appellants, asserted that from May 23,1919 , when the first proposal for change was introduced in the Grand Conseil, until January 30, 1921, when the people of Fribourg voted to accept the change, no mention was made in the legislative chamber of any kind of quorum. During the debates on the bill immediately introduced to add this qualification, three deputies of the Radical Party are quoted as asserting that a quorum law would be contrary to the will of the people as expressed so recently at the polls. One of these protesting deputies maintained that such a law would be unconstitutional.

M. Nordmann concluded that the arbitrariness of the Grand Conseil is especially remarkable since it enacted the law despite these protestations, on March 19, 1921, only six weeks after the people had clearly expressed themselves in favor of a "pure" system of proportional representation. ${ }^{30}$ It is submitted that the facts presented do not justify this conclusion, which seems to be a transparent example of "begging the question." As a matter of fact, if the limited historical study is put into its proper setting, the opposite conclusion should have been reached. An American court, if presented with a law or constitutional provision of doubtful meaning, would surely apply a rule of "practical construction": what was done by Congress immediately after the adoption of a constitutional amendment or the enactment of a law is viewed as a valid interpretation of the doubtful texts. In the case of Article 36, it must be remembered that the exact text of the revision was the product of the Conseil d'Etat and the Grand Conseil in November, 1920. According to the rule of "practical construction," the conclusion should have been that the 15 per cent quorum law was perfectly consonant with the amended provision in the cantonal constitution.

This argument is greatly re-enforced by consideration of the channels provided in cantonal and federal law, whereby an efficacious protest could have been raised at the time, had the electoral law of March 19, 1921 been a mockery of proportional representation and a betrayal of public confidence, as appellants and the Federal Tribunal characterized the work of the Grand Conseil. First, any citizen in Fribourg could have appealed immediately to the Federal Tribunal and asked for a declaration of nullity, for, according to Swiss law, it is not necessary to show an actual personal injury as a prerequisite for an entrée

\footnotetext{
34. La Liberté, March 30, 1962, p. 15.

35. EXPOSE SUR LES DELIBERATIONS, op. cit. sipra note 16.

36. Le recours de Droit Public, pp. 8, 9, Geissbühler v. Fribourg, Grand Conseil, supro
} note 2. 
to the high court. ${ }^{37}$ Appeal, furthermore, must be had within thirty days ${ }^{88}$ generally before the law would have set executive wheels turning-in order to elicit a decree of nullification. After that, only applications of the law in ench individual case are subject to review and possible reversal. Surely a deputy of a minor party likely to be adversely effected by the quorum in the approaching elections of December, 1921 had compelling reason to make such an appeal had he seriously entertained doubts as to the constitutional infirmity of the protested law.

Second, Article 28bis of the cantonal Constitution provides that "6000 citizens have the right to ask for the elaboration, the abrogation or the modification of a law." Since the revision in Article 36 had won overwhelming endorsement on January 30,1921, by a vote of 15,796 to 902 , it seems certain that the spirit of 6,000 Swiss citizens in Fribourg could have been aroused effectively to demand an abrogation or modification of the quorum law had it in fact been a clear mockery of the revision and an utter disregard of their expressed will. But such action was neither taken nor suggested.

Third, Article 79 of the Fribourg Constitution provides, "The total or partial revision (of the Constitution) may take place: 1 , when it is asked for, following the prescriptions of the law, by at least 6000 active citizens. 2 , when it is decreed by the Grand Conseil." It seems safe again to assert that if 15,796 Fribourg citizens had voted for the revision, at least 6,000 could have been found to amend out that which allegedly had "made a farce" of what the people had so recently amended in. What strange föhn ${ }^{30}$ was it that so enervated in March those independent-minded Swiss spirits who had been so quickened in January?

As mentioned earlier, the Court admitted that the Grand Conseil of Fribourg could modify the system of proportional representation by demanding a quortum, even though Article 36 carries no provision for addition of such a qualification. The majority warned, however, that it was not permissible to dilute the method by modifications which so change its "nature" that it could no longer be defined as proportional representation. ${ }^{40}$ The Federal Tribunal ruled that a 12.4 per cent quorum had produced the forbidden adulteration, while a 6.6 per cent

37. Lot Féférale d'Organisation Judictarre, Art. 85, 88 (1943); HeFtr, De $2 \Lambda$ Qualite pour Recourtr dans ia JuRisdiction Constitutionnelle du Truuunal Federal 60 (1958). Also, Couchepin v. Valais, Grand Conseil, Recuein Officiet des Arrets du Tribunal Federal 87, I, at 37 (May 15, 1961). In this case, the law was enacted on November 19,1960, and the appeal by a citizen of the canton was taken to the Federal Tribunal on December 9, 1960, before the law went into effect. The Federal Tribunal set the law aside. Thus a "virtual" interest or a lively "fear" of injury suffices.

In the Fribourg elections of 1956, the Socialists in the Lac district and the Peasants and Independents in the Gruyere district each lost one seat by reason of the quorum, but there was no appeal. 1956 Bulletin des Lors de Fribourg 104, 107.

38. Lot Fédérale d’Organisatron Judictatre, Art. 89 (1943).

39. The "Föhn" is a wind which, according to the Swiss, has strange effects upon bodies and spirits, producing a feeling of apathy and weariness.

40. Geissbühler v. Fribourg, Grand Conseil, supra note 15, at 274. 
quorum had not.41 Just how much solvent could constitutionally be added before debasement would be reached was a question the court's opinion left unanswered.

The approach made by the judges to this problem is not entirely satisfactory. It presumes that proportional representation has a specific "nature"-something that political scientists themselves might not admit. But, granted that it has such a nature, is it the function of the judiciary to sort out and label the several elements-there are others besides the quorum-that bring about the prohibited dilution? In its quest for the "nature" of proportional representation, the court was forced to discuss the purpose of the systen-and so it would seem, to register the opinion that it is better than other electoral methods, something not proper for the judiciary. It then singled out for condemnation but one of the factors that can be a contribution to its "corruption." In this part of its discussion, the court necessarily considered the "equality before the law" argument, for the proponents of proportional representation generally point out that its chief advantage over the majority system is that it gives equal weight to every vote, no matter what the domicile of the elector. The court admitted that splintering parties was a result of proportional representation, that it made government by stable majorities difficult, and that the quorum was a legitimate device to prevent a shattering of parties and an excessive multiplication of political groups. But the 15 per cent quorum went beyond what was reasonable and defeated all the values for which the system was established.4

The Tribunal borrowed examples from the brief of the appellants to demonstrate just how the "equality" clauses were violated and the votes of many electors in Fribourg unfairly diluted by reason of the quorum. ${ }^{33}$ The adherents of a particular party, observed the court, may be fairly large throughout the whole canton, but under 15 per cent in one district. Nonetheless, according to a system of unqualified proportionality, the electors in the latter district might be entitled to one or two representatives, who, if joined to their brethren from other parts of the canton, would allow them an effective role in the legislative assembly. The electoral law of Fribourg, the court continued, theoretically could exclude as many as 29 per cent of the voting population of a district belonging to two groups, appreciable in number, but each slightly below the 15 per cent requirement. In effect, they are stripped of their right to vote and thereby denied equality under the law. Moreover, an assembly in which 29 per cent of the voters in one or more districts have been excluded can scarcely pretend to represent the electoral body on a proportional basis.".

The court had other arrows in its quiver. The Fribourg law virtually compels minority groups to conclude alliances to assure success at the polls, and thus the elector is forced to give his vote to a party which he has no desire to support. Liberty of association thus is restricted. In addition, said the majority,

\footnotetext{
41. Id. at 277 .

42. Id. at 275-76.

43. Ibid.

44. Id. at $275-77$.
} 
the delegation which is sent to the assembly from these parties of compromise do not always give an exact idea of the strength or views of the respective groupings that formed them. These drawbacks may be allowable for unimportant groups, but when it is a question of political parties, each of which is almost 15 per cent of the electoral body, proportional representation in any true sense is perverted.

It is difficult to accept the validity of these arguments. The same law was administered without discrimination in all the districts of Fribourg for the December elections of 1961. No matter how regrettable may be the failure of the Workers and Employers Party of the Lac District to receive a single seat in the new assembly, the result was not due to an application of the law which differed from its application in another district. The votes of adherents to this party in the Lac District were "diluted," "wasted," "uncounted" not because of "unequal treatment under the law," but solely because of domicile-a factor beyond the power of the law to control. In a like manner, a Republican vote in most districts in New York City goes "uncounted" and a Democratic vote in many upstate districts is "wasted." The words from Justice Frankfurter's dissent in Baker v. Carr seem appropriate :45

Appellants invoke the right to vote and to have their votes counted. But they are permitted to vote and their votes are counted. They go to the polls, they cast their ballots. ... One cannot speak of "debasement" or "dilution" of the value of a vote until there is first defined a reference as to what a vote should be worth. What is actually asked of the Court in this case is to choose among competing bases of representation-ultimately, really among competing theories of political philosophy-in order to establish an approprite frame of government for the State of Tennessee and thereby for all the States of the Union.

The hypothetical case presented by appellants, according to which 29 per cent of the voters in one district could fail to receive a single seat in the Grand Conseil, can also be viewed with misgivings. But the same result is possible-in some instances it is an actuality-under electoral systems in Switzerland in which the Federal Tribunal could never find a constitutional infirmity. A 10 per cent quorum, which in Geissbiihler the court indicated it would probably accept, ${ }^{46}$ could work the same type of "inequity" if each of three parties received only 9.5 per cent of the votes.

The advocate for the appellants used the "equality" argument to support the claims of both his clients, the Workers and Employers in the Lac District, who had received 12.4 per cent of the votes, and the Social Democrats in the District of the Singine, who had won 6.6 per cent in the December election. But in the District of the Glane the Socialist Party also gathered 6.6 per cent of the total suffrages and yet received no seat in the assembly, not because of operation of the quorum, but simply because the Glane District has only 12 deputies, and 6.6 per cent of 12 is less than one. A more striking case is that

45. 369 U.S. at $299-300$.

46. La Liberté, March 30, 1962, p. 15. 
of the District of the Veveyse, which, because it is allotted only six deputies in the Grand Conseil of Fribourg, has an automatic electoral quotient of 16.7 per cent. In the election of December, 1961,47 to reach this quotient it was necessary for a party to poll 1,739 votes, while only 1,565 votes were required to attain the 15 per cent quorum. Here three parties presented lists which won a total of 10,439 votes. On the supposition that Party $A$ had received 8,695 or 83.5 per cent of these votes, it would have gained all six seats, even if Party B had garnered 1,618 votes or 15.4 per cent and Party $C 116$ or 1.1 per cent. In other words, although in the District of the Lac with 15 deputies it was an unconstitutional denial of equal treatment under the law to withhold seats from a party on the ground that it attained only 12.4 per cent of the vote, in Veveyse it would have been perfectly in accord with proportional representation, and therefore constitutional, to refuse seats to Party B, which won 15.4 of the total votes cast.

If voters in the District of the Veveyse conclude that the electoral law there is unconstitutional, they might urge the Grand Conseil to redistrict the Canton of Fribourg and to give it more territory and more seats. But there is no way to get a judicial ruling from the Federal Tribunal unless the case should actually pass from the hypothetical to the real order. ${ }^{48}$ The aggrieved 15.4 per cent might then appeal to the high court from a concrete decision of the Grand Conseil. In the meantime, one can only speculate on how many of the doleful happenings lamented by the Geissbithler majority would have come to pass in Veveyse-the forced coalitions, the denials of free association, the inadequate reflection of political views in the cantonal legislature.

The weakness of the "equality" argument is further exposed by an exploration of electoral conditions in the adjacent Canton of Vaud. Article 33, section 3, of the Constitution of Vaud, as revised in 1948, reads, "Election is held according to the majoritarian system in cercles [electoral districts] with one or two deputies and according to the system of proportional representation in the other cercles." This restriction on the proportional system affected 17 of the 60 districts. Surely, it might be asked, was this not on its face "unequal treatment under the law?" And yet the Federal Assembly-whose decisions are beyond the reach of the Federal Tribunal-had in 1948 given its stamp of approval to this revision in the Vaud Constitution, ${ }^{49}$ as is required for all such amendments by Article 85, chap. 7, of the Federal Constitution, and especially by Article 6.

Perhaps the people of Vaud and its legislature recognized the injustice of the 1948 provision. At any rate, in 1960 the Grand Conseil modified Article 33 to read in part: 50

47. See note 14 supra.

48. Loi Fédérale d'Organtsation Judictatre, Art. 89 (1943).

49. FrutLle Federale III, 1169 (1948).

50. 157 Recueth des LoIs et Decrets du Canton de Vaud 23 (1960), and 158 id. 490 (1961). 
2. The canton is divided into 30 electoral arrondissements the boundaries of which are determined by law.

3. The election is held according to proportional representation.

The decree of the Grand Conseil promulgating this modification begins, "For the purpose of introducing proportional representation for all the deputies: ...." Such a preamble is highly significant, and curious, because the legislature thereby made proportional representation merely theoretical in many areas by keeping thirty districts for a canton the size of Vaud. In 17 districts, as they were later determined by law, there are five or fewer seats, in seven only three. In districts with three seats, the quotient-a veritable quorum - is 33.4 per cent, and in districts with four seats it is 25 per cent. Again, it must be remembered, the Federal Assembly gave its blessing to the revisions in Article 33. Perhaps the Grand Conseil of Vaud, working under the strictures of this 1960 provision, could have so drawn 30 electoral districts all of which would have a sufficient number of deputies to make proportional representation a practical possibility. Supposing this, and supposing that someone could bring an appeal before the Federal Tribunal on the "equality" argument, would the court have the daring to order the Legislature of Vaud to undertake a complete redistricting of the whole canton?

In this connection, the case of Doser w. Valais, Grand Conseil br seems pertinent. Article 84 of the Valais Constitution reads thus:

The voting is by district, according to the system of proportional representation. The mode of applying this principle will be determined by law:

In 1937 three parties competed for the four deputies in one of the districts. One party with 65 per cent of the votes was awarded all the seats, although another party received 19.4 per cent, and the third party 15.6 per cent. According to the cantonal laws of $1920,{ }^{62}$ a party not reaching the electoral quotient is eliminated in the distribution of seats. Protesting application of the law to themselves, the party with 19.4 per cent argued before the Federal Tribunal that the law was contrary to the constitutional provision adopted in Jantury, 1920.53 Appellants' thrust was powerful, for elections to the National Council had just been held in November, 1919 for the first time under the "pure" proportional system. Moreover, as appellants asserted, the Valais Grand Conseil in its 1919 deliberations on the proposed amendment had pronounced itself in favor of a system like that of the federal government. But in its Doser decision, the Federal Tribunal rejected the appeal, asserting that the Grand Conseil could not be charged with arbitrariness. It noted:

51. MS in the Records of the Tribunal Féderal at Lausanne, Switzerland. The case is listed in 63 Recueir. OfFicted des Lors et Ordonnances 406, as a decision of September 17, 1937, but the opinion and judgment have not been printed. Valais is a canton about equal to Fribourg in population but somewhat larger in territory.

52. LoI sur les Elections, Art. 12, 13, 14 (November 20, 1920).

53 MS, op. cit. supra note 51, at 6 . 
[T] he concern in re-acting against an excessive dispersion of electoral forces and against the splintering of parties, by favoring the more numerous parties and at the same time seeking to attenuate electoral strife . . . is legitimate in itself. . . .54

It seems strange that in the Geissbiihler case the Federal Tribunal made no mention of the Doser decision, either to reverse or to distinguish it.

The practical question of enforcement of the Geissbiihler decree merits consideration. In Baker v. Carr this question was of great concern, provoking Mr. Justice Frankfurter to write: $: 5$

In all of the apportionment cases which have come before the Court, a consideration which has been weighty in determining their nonjusticiability has been the difficulty or impossibility of devising effective judicial remedies in this class of case. An injunction restraining a general election unless the legislature reapportions would paralyze the critical centers of a State's political system and threaten political dislocation whose consequences are not foreseeable. A declaration devoid of implied compulsion of injunctive or other relief would be an idle threat. Surely, a Federal District Court could not itself remap the State. . . .

Problems almost identical are raised in respect to the decision in the Geissbiihler case. Article 39 of the Federal Law on the Organization of the Judiciary reads:

The cantons execute the decrees of federal judicial authorities in the same manner as judgments passed by the power of their own tribunals.

In case of a failure to execute, recourse is had to the Federal Council, which takes the necessary measures.

This is not very satisfying. If the Grand Conseil of Fribourg had failed to award the two contested seats to the Workers and Employers Party, there would seem to have been no way to break their stubbornness short of a dispatch of troops by the federal executive authorized to arrest the recalcitrants in the Fribourg assembly and to occupy the canton until compliance was forthcoming. Fortunately, for the sake of law and order, the Grand Conseil did complybut only with the very letter of the court's decision. They deprived the Conservative-Social-Democratic Party of one seat and the Radical-Democratic Party of another and bestowed them upon the Workers and Employers Party, merely noting that the quorum was 12.4 per cent. ${ }^{\text {so }}$

54. Id. at $12-13$. In this election 5108 votes were cast, which, according to the Valais system, resulted in a quotient of 1030 . Party B, with 986 votes, was entitled to none of the four deputies because of the special demands of the Valais law. Had there obtained in Valais the quotient system used by the federal government-and also by Fribourg-Party $B$ would have received one seat.

55. 369 U.S. at $327-28$.

56. Feuille officielle du Canton de Fribourg, May 19, 1962, p. 413. Here are the possibilities that are open to the Grand Conseil in the future: It could by a ncw law reduce the quorum to 10 per cent or to some other percentage which it might deem acceptable to the Federal Tribunal. It could consider the 12.4 per cent quorum to be the prevailing law by court decree and continue to hold elections accordingly. Or it could accept the decision of the Federal Tribunal as applicable only to the case involving the District of the Lac. Since 
There remains for treatment here the question of the court's jurisdiction. The Geissbiihler and Baker cases are similar in that neither involved a coordinate branch of the same government, but only the legislature of a canton or State. It would seem that in each case the respective federal court had jurisdiction, except insofar as it might care to limit itself out of judicial prudence, respect for federalism, deference to the legislative will, or impossibility of enforcement. In the 1946 case of Colgrove v. Green, ${ }^{\text {b7 }}$ the Supreme Court of the United States restrained itself upon the doctrine of "political questions." In response to a claim that Illinois did not have a "republican form" of government as required by Article 4 of the federal Constitution, the Court declared that the matter should be handled solely by Congress, which under Article I, sections 4 and 5, of the Constitution, is empowered to apply any necessary remedies. Since the Congress, however, had not taken action against the legislature of Illinois, but, on the contrary, had been seating Representatives from the contested districts, the presumption that the State's government complied with Article 4 prevailed. Had the Court rendered a contrary judgment, an unseemly impasse between Congress and the judiciary could have resulted.

The Geissbiihler decision might possibly lead the Federal Tribunal to this kind of impasse with the Federal Assembly. If somebody from Vaud or from other cantons with small electoral areas appealed to the Federal Tribunal on the grounds that districts of three or four deputies make proportional representation a practical impossibility, would they be told that the matter was equivalent to a "political question"? By approving the Constitution of the canton involved with its particular districts therein mentioned, had the Federal Assembly already given its response and had it thus foreclosed the isste to judicial determination? Certainly this would be the judgment of the Federal

the high court of Switzerland has no power to annul the quorum law of Fribourg (sce note 23 supra and accompanying text), the 15 per cent requirement is still legal and could be utilized in the next election. Indeed, the law could again be attacked, but only by parties adversely affected through an application of the law and only after the election returns are in and verified by the Grand Conseil-i.e., in December, 1966. Since Swiss courts do not bind themselves strictly to stare decisis (see Dubs, Praxis ANderungen 9 (1949)), an appeal to the Federal Tribunal might be given a reception in 1966 quite different from that of 1962 . This is not entirely impossible, especially since there is no certainty that all or any of the five concurring judges in the Geissbithler case would be appointed to hear the appeal. Since the Geissbiihler decision has elicited so much criticism, even in judicial circles, a prediction of a reversal for 1967 is not too daring.

57. 328 U.S. 549 (1946). Article 73 of the Federal Constitution reads:

Les élections pour le Conseil national sont directs. Elles ont liett d'après le printcipe de la proportionalité, chaque canton ou demi-canton formant un collège électoral -...

La législation fédérale édictera les dispositions de détail pour l'application de ce principe.

Since four cantons have only two deputies each and four semi-cantons have only one each, the blessings of paragraph 1 of article 73 are entirely denied to them. Query: Does paratgraph 2 place an obligation on the National Legislature to bring them under the coverage of paragraph 1, i.e., by a law redrawing cantonal boundaries? (In Switzerland, this question is foreclosed to judicial determination. See note 9 supra and accompanying text.) 
Tribunal if anyone were so bold as to ask it to decide that the allotment of seats to each canton for the National Council was a denial of "equality before the law" to people in eight or ten of the smaller cantons. There is the slight possibility that in the Geissbiihler case itself the court came close, indirectly, to infringing upon a prerogative of the Federal Assembly. Article 36 of the Fribourg constitution did not receive its stamp of approval from the Parliament until June 25, 1921. ${ }^{58}$ The 15 per cent quorum law, drafted to elaborate the constitutional provision, was enacted on March 19, 1921, two months earlier. ${ }^{59}$ Is it possible to say that the Federal Assembly endorsed not only the naked provision but the provision as already interpreted by the Grand Conseil in its electoral law, which might then have been considered virtually a part of that unadorned phrase in the constitution ?co

Granted that the Federal Tribunal had jurisdiction-and this seems certain -should not the court have been more eager to seek reasons justifying the 15 per cent quorum? Or, to put it another way, unless there could be no rational grounds for such a law, should not the court have refused to declare it unconstitutional? Mr. Justice Harlan, dissenting in the Baker case, wrote:01

And so long as there exists a possible rational legislative policy for retaining an existing apportionment, such a legislative decision cannot be said to breach the bulwark against arbitrariness and caprice that the Fourteenth Amendment affords .... .

These conclusions [that the policy was not clearly arbitrary] can hardly be escaped by suggesting that capricious state action might be found were it to appear that a majority of the Tennessee legislators, in refusing to consider reapportionment, had been actuated by self-interest in perpetuating their own political offices or by other unworthy or improper motives. Since Fletcher $v$. Peck, 6 Cranch. 87, was decided many years ago, it has repeatedly been pointed out that it is not the business of the federal courts to inquire into the personal motives of legislators ..... The function of the federal judiciary ends in matters of this kind once it appears, as I think it does here on the undisputed facts, that the state action could have rested on some rational basis.

Appellants in the Geissbïhler case spent considerable time arguing that the quorum law was enacted by the majority of the Grand Conseil in order to keep certain minority parties out of the legislative chamber, specifically the Socialists, "the party of disorder."62 And the Federal Tribunal, it would seem, was influenced in its thinking by such charges of "unworthy motives." The court admitted in the Geissbiuhler opinion, however, that the desire to prevent the disintegration of parties and the multiplication of groups are "pertinent motives." "They justify even the principle of the quorum as one of the possible

58. 37 RECUEIL des LoIs FederaIes 536.

59. 1921 Bulletin DES LoIs DE FrIBourg 68-77.

60. These possibilities are offered purely as early speculations. They should not be interpreted to indicate a commitment by the author, one way or the other.

61. 369 U.S. at 337-38.

62. EXPose sur IES DeImerations, op. cit. supra note 16 , at 7. 
modalities of the system of proportional representation." ${ }^{\text {o3 }}$ In the Doscr case, ${ }^{04}$ moreover, the Federal Tribunal upheld Valais's unique quotient law, which disqualified parties gaining less than 20 per cent of the votes, and in so doing the court said that it was legitimate to "re-act against the excessive dispersion of electoral forces ... . by favoring the larger parties and at the same time seeking to attenuate electoral strife." 65

Relative to the motives which induce legislatures to enact quorum laws, it cannot be said that such strictures are always demanded by the major party and fought by minorities. To the contrary, a strong major party commanding 60 per cent of the legislature, with a clear-cut political credo which wins the unwavering allegiance of all its members, may have no fear of defections in an election under "pure" proportional representation. Indeed, it may actually prefer such a "pure" system as a means of dispersing its political enemy. On the other hand, the quorum may be welcomed by minor groups as the sole means of salvation against the centrifugal tendencies within their organizations. In an assembly of 130 members, the controlling party of 70 is quite invincible by any force which splintered regiments of six or ten deputies under different banners and divided counsels can send against it. But legislative campaigns may be quite different if the majority were made to battle against a sizable party of 55 , all rallying behind an articulate leader with a consistent program. Or it may be that the Socialists oppose the quorum rule in a district where they can attract no more than 7 per cent of the vote, but support it in another district where they reach a respectable 40 per cent. There being so many possible motives which align legislators for or against modification of proportional representation, it seems hardly proper for the judiciary to isolate one motive held by some deputies and condemn the quorum because of it.

The final point raised in both the Geissbiihler and Baker cases concerns the principles of federalism and democracy. Mr. Justice Harlan, speaking against the Baker decision, wrote: $:^{66}$

The fact that the appellants have been unable to obtain political redress of their asserted grievances appears to be regarded as a matter which leads the Court to stretch to find some basis for judicial intervention.

In the United States it may well be that when situations like that in Tennessec develop, there is no remedy short of intervention by the judicial arm. But in Switzerland abuses by the legislatures are not beyond correction by other means. In Fribourg the people possess both the legislative and the constitutional initiative, and with these two weapons at their disposal they could have settled the "quorum" question without invoking aid from the court. Appellants, perhaps, protested against the chaffing chores of soliciting signatures and the

63. Tribunal Fédéral, March 28, 1962, $110 \mathrm{~J}$. Des Tribunaux I, 271, 275 (Swit.).

64. 63 RecueIL OfFictel des LoIs et Ordonnances 406 (1937).

65. MS, op. cit. supra note 51 , at 12 .

66. 369 U.S. at 339. 
dull duties required for putting the necessary machinery into operation. ${ }^{.7}$ But it should be recalled that it was through an amendment that Article 36 was revised in 1921, even though the Grand Conseil was dominated then, as now, and to the same degree, by the Conservative Party. In the Geissbinhluer case forty years after, the Federal Tribunal, presented with what it deemed a case of denial of electoral rights, had two possible answers for the alleged infringement : correct the abuse by judicial decree, or leave it to the democratic process. The judges elected the first. An observation by a respected professor of constitutional law, Charles Fairman, commenting on Colgrove v. Green, furnishes mutatis mutandis, a fitting conclusion to this article:

[T] he Court might well reflect upon the consequences to which the two answers respectively would lead. Would American [Swiss] democracy be strengthened if equality in representation were secured to the voters by judicial action, regardless of their own lethargy? Would the Court do well to correct an old evil over which the legislative branch [the people] has always had full power but which it has consistently failed to remedy ? $^{\circ S}$

67. Only once during the period of 40 years since 1921 had the people of Fribourg attempted to use the constitutional initiative, provided by Article 79 of the cantonal constitution to alter the quorum. That was in 1953, and the effort came to naught because the proposal contained "a multiplicity of issues," which is itself a violation of the cantonal constitution. Part 4 of the multiple project asked for lowering the quorum to 10 per cent. The Federal Tribunal rejected an appeal from a decision on the Grand Conseil which had ruled on the "multiplicity" issue. 1 Recurir Officrel des Arrets du Trisunal Feneral 192, 202 (1955). See also Nordarann, op. cit. sipra note 26.

68. Fatrasan, AMrerican Constitutional Dectsions 58 (rev. ed. 1950).

Note Mr. Justice Harlan's lament that the Court's decision in Baker "cuts deep into the heart of our federal system." 369 U.S. at 301. Federalism was impaired in both cases, but in the Swiss case, democracy, as implemented by peculiar Swiss institutions, seemed to be even more sinned against. In addition to the many similarities mentioned above, the following deserves a word. Article 4 of the American Constitution and article 6 of the Swiss Constitution impose a "republican form" of government upom the states or the cantons. In Baker v. Carr, article 4 was clearly involved. See 369 U.S. at 297-307. Mr. Justice Frankfurter, dissenting, remarked, "To divorce 'equal protection' from 'Republican Form' is to talk about half a question." Id. at 301. In the Geissbinhler case, the Federal Tribunal said little if anything about this point. But when speaking before the Grand Conseil and in recommending rejection of the appeal on December 27, 1961, the chairman of the special electoral commission spoke thus: "[T] he principle of equality before the law must be examined in the light of Article 6." BuLI. du Grand Conserr, Dec. 1961, p. 991. 